\title{
Pengaruh Relaksasi Autogenic Training dan Progressive Muscle Relaxation Terhadap Hasil Shooting Sepak Bola di PSKC Kota Cimahi
}

\author{
Ruslan Rusmana ${ }^{1}$, Budiman $^{2}$, Ricky Ferari ${ }^{3}$ \\ ${ }^{1}$ Jurusan Pendidikan Olahraga, Prodi PJKR STKIP Pasundan, Indonesia \\ ${ }^{23}$ STKIP Pasundan, Indonesia \\ ruslan.rusmana24@gmail.com ${ }^{1}, \underline{\text { budiman13@gmail }{ }^{2} \text {,ferrariricky@gmail.com }{ }^{3}}$
}

Menerima: 09 September 2020; Revisi: 02 November 2020; Diterima: 10 November 2020

https://doi.org/10.24036/MensSana.050220.10

\begin{abstract}
This study originated from the results of observations that researchers encountered and felt in the field, where it was suspected that progressive muscle relaxation mental training and autogenic training affected the results of the soccer shooting penalty at the Cimahi City PSKC. This type of research is experimental, the population is PSKC players who play in league two and the elite program which can be 33 people. The sampling used was total sampling. The data collection technique is the result of a shooting penalty test with one chance. The data obtained were analyzed by pretest normality test PMR 0.066, pretest AT 0.324 and posttest PMR 0.055 posttest AT 0.333 then homogeneity test that the two data is known by the results of homogeneous data and paired test results $P M R$ and AT to have a significant effect on the PMR numbers 0.521 and AT 4,392. With the results, there is no difference in the effect between PMR and AT on the results of soccer penalty kicks.
\end{abstract}

Keywords: Autogenic Relaxation Training, Progressive Muscle Relaxation, Shooting Penalty, and Soccer

Abstrak

Penelitian ini berawal dari hasil observasi yang peneliti temui dan rasakan dilapangan, di duga latihan mental progressive muscle relaxation dan autogenic training berpengaruh terhadap hasil shooting penalty sepak bola di PSKC Kota Cimahi. Jenis penelitian adalah eksperimen desain yang digunakan yaitu randomize pretest postest, populasi adalah pemain PSKC yang bermain di liga dua dan elite pro yang berjumlah 33 orang. Pengambilan sampel yang digunakan adalah total sampling . teknik pengambilan data adalah dengan test hasil shooting penalty dengan kesempatan satu kali. Data yang diperoleh dianalisis dengan uji normalitas pretest PMR 0,066, pretest AT 0,324 dan postest PMR 0,055 postest AT 0,333 kemudian di uji homogenitas bahwa kedua data diketahui dengan hasil data homogen dan hasil uji paired PMR dan AT memberikan pengaruh yang signifikan dangan angka PMR 0,521 dan AT 4,392. Dengan hasil tidak terdapat perbedaan pengaruh antara PMR dan AT terhadap hasil shooting penalty sepak bola.

Kata Kunci: Relaksasi Autogenic Training, Progressive Muscle Relaxation, Shooting Penalty PENDAHULUAN

Berdasakan pengamatan dilapangan peneliti bahwasanya hasil kemampuan tendangan penalty sangat menentukan kemenangan saat pertandingan terutama pada situasi-situasi tertentu. Hal tersebut sama dengan menurut (Wunderlich et al., 2020) menunjukkan bahwa pelatih tim yang lebih lemah benar kapan mencoba mencapai adu penalti alih-alih bermain untuk menang dalam waktu reguler, sebagai probabilitas untuk memenangkan adu penalti adalah sekitar $40 \%$ bahkan jika bermain melawan banyak lawan yang lebih kuat dan memiliki peluang minimal untuk menang dalam waktu reguler. 
Penemuan dari hasil penelitian (Jamil et al., 2020) bahwa pelatih dan pemain harus memberikan perhatian khusus pada panjang run-up, arah tendangan, jenis tendangan dan kaki mana yang menerima penalti karena variabel-variabel ini secara langsung mempengaruhi keberhasilan penalti dan berada dalam kendali pengambil penalti. Kemudian (Makaruk et al., 2020) Kombinasi teknik dengan mental juga menunjukkan lebih tinggi mencetak gol dan akurasi tembakan yang lebih baik dibandingkan dengan tidak memanfaatkan faktor perhatian atau motivasi.

Bergantung pada tuntutan spesifik dari olahraga masing-masing, tujuan intervensi, dan sejarah dan preferensi individu atlet, intervensi dan teknik psikologis yang berbeda dapat diterapkan untuk mengatur proses dan keadaan psikologis yang relevan dengan kinerja (Mattle et al., 2020).

Pemain sepak bola dalam latihan atau pertandingan yang sesungguhnya selalu dituntut untuk menampilkan performa terbaiknya (Horikawa \& Yagi, 2012). Namun performa terbaik itu tidak selamanya dapat ditunjukan apabila atlet atau pemain tidak dapat mengelola kecemasan (Sangari et al., 2012).

Kecemasan dari atlet dapat disebabkan dari berbagai faktor misalnya diberi tugas yang berat, lawan yang dinilai berat, beban karena harus memenangkan pertandingan dan faktor psikologis lainnya (Komarudin, 2015) mengatakan bahwa kecemasan adalah ketegangan mental yang biasanya dengan gangguan tubuh yang menyebabkan individu yang bersangkutan tidak berdaya dan mengalami kelelahan.

(Thompson et al., 2020) bahwa kelelahan mental tidak lazim di prapertandingan, maupun di beberapa skenario khusus sepak bola lainnya, tetapi disajikan secara subyektif setelah pertandingan dan 24 jam setelah pertandingan.. Dampak dari kelelahan itu yang mempengaruhi kemampuan seorang pemain. Bahwa ada hubungan antara faktor psikologi misalnya kecemasan dan stress yang menimpa atlet saat pertandingan dengan kemampuan shooting saat penalty (Horikawa \& Yagi, 2012). stress yang dialami dapat menyebabkan perubahan irama sirkadia dan keluhan-keluhan fisik.

Oleh karena itu dibutuhkan metode yang diberikan kepada atlet untuk dapat melakukan pengelolaan kecemasan dan ketegangan saat pertandingan (Astuti Ary, Anggorowati, 2017). Diperkuat oleh hasil penelitian yang mengatakan kecemasan pada atlet merupakan hal yang bisa memberikan dampak negatif (Effendi, 2017).

Pentingnya ketahanan mental yang dimiliki pemain sepak bola disaat latihan maupun pertandingan diyakini akan berdampak pada peningkatan keterampilan bermain sepak bolannya. Mental skill training for sport is designed to produce psychological state and skills and strategies to cope with the various demand of sport competition. Maksudnya latihan keterampilan mental merupakan dasar kesehatan mental atlet yang terkait dengan keterampilan kognitif dan strategi yang harus dipelajari untuk mengatasi berbagai tuntutan dalam pertandingan olahraga.

Oleh karenanya, maka pemain harus dilatih mentalnya dalam proses latihan yang dilakukan secara sistematis, kontinu dan berkesinambungan Pemain yang dilatih mentalnya tentu akan semakin terampil dalam mengatasi masalah emosi dan masalah mental.

Salah satu intervensi teknik yang bisa diterapkan dan dicobakan untuk membantu meningkatkan keterampilan bermain sepak bola adalah melalui teknik relaxation autogenic training. Teknik tersebut merupakan proses latihan mental dengan melibatkan unsur konsentrasi, mengarahkan tindakan ke suatu tujuan sesuai rencana, pengendalian perasaan dan psikofisik.

Namun sejauh ini dapat dikatakan bahwa data empiris mengenai teknik relaxation autogenic training terhadap keterampilan bermain sepak bola masih kurang. Relaxation autogenic training lebih sering digunakan dalam dunia kesehatan yang berhubungan dengan psikologis pasien. 
Maka tujuan dari penelitan ini adalah menganalis dampak relaxation autogenic training tehadap peningkatan keterampilan bermain sepak bola.

Hasil penemuan dari penelitian temuan mendukung gagasan bahwa kesulitan masuk mendefinisikan dengan jelas batas menta fatigue dari pemantauan saat ini dan pengelolaan MF di lingkungan terapan (Russell et al., 2019). Metode pelatihan yang dapat digunakan untuk mengurangi ketegangan otot dikarenakan kecemasan yaitu metode progressive muscle relaxation.

Pelatihan relaksasi bisa menjadi pilihan yang cocok dan intervensi efektif untuk mengurangi kecemasan dan depresi (Hampson et al., 2020). Progressive muscle relaxation merupakan metode latihan yang dilakukan dengan menegangkan otot-otot pada seluruh tubuh sebelum membuat otototot tersebut relaks. Metode latihan relaksasi ini harus disusun secara sistematis mulai dari otot bagian atas sampai pada otot bagian bawah pada tubuh.

Misalnya otot bagian lengan, otot bagian kepala (mulai dari dahi, mulut, pipi, bibir, lidah); selanjutnya otot leher, otot bahu, otot dada, otot perut, otot punggung sampai pada otot bagian bawah yaitu otot tungkai. Tujuan dari relaksasi ini agar nanti atlet bisa dengan cepat menjadi relaks kalau dibutuhkan.

Keefektifan progressive muscle relaxation dalam mengurangi kecemasan dan ketegangan terletak pada latihan yang melibatkan kontraksi otot secara aktif yang kemudian diikuti dengan relaksasinya. secara fisiologi ketika otot berkontraksi berarti otot memendek, sedangkan dalam keadaan relaks berarti otot memanjang, bahkan otot setelah kontraksi kemudian relaksasi akan kembali memanjang dan lebih relaks dibandingkan sebelum kontraksi.

Adapun efektivitas dari latihan ini yaitu mengatasi gejala kecemasan seperti nervous, gugup, merasa gelisah sebelum kompetisi, memberikan kesempatan untuk istirahat, meningkatkan kualitas tidur, mengatasi akumulasi ketegangan pada kompetisi dan mempercepat pemulihan. Metode ini dilakukan selama kurang lebih 20-30 menit selama latihan.

Lama waktu progressive muscle relaxation selama latihan disesuaikan dengan sifat-sifat dan kepribadian setiap pemain. Sedangkan sebelum pertandingan latihan progressive muscle relaxation hanya dilakukan dalam waktu yang relatif singkat dalam waktu beberapa menit saja. Fungsi dari latihan progressive muscle relaxation sebelum pertandingan adalah mengurangi kecemasan yang dapat mempengaruhi performa pemain saat shooting bola.

Pengaruh kecemasan terhadap performa pemain berasal dari ketegangan otot dari pemain akibat cemas yang melanda selama pertandingan. Metode ini dapat melatih pemain untuk memiliki kemampuan membuat otot relaks ketika otot dalam keadaan tegang dalam situasi kritis sekalipun, misalnya selama pertandingan berlangsung.

Atlet elite berhasil menggunakan teknik progressive muscle relaxation secara rutin untuk mengatur energi fisik mereka, hal tersebut sejalan dengan pendapat Murphy dalam (Komarudin, 2015) bahwa metode ini efektif mengurangi kecemasan fisik dan insomnia pada hari-hari sebelum kompetisi. Progressive muscle relaxation is highly effective in reducing acute feelings of stress and anxiety in patients (Lolak et al., 2010) inti maksud pernyataanya adalah Relaksasi otot progresif sangat efektif dalam mengurangi perasaan stres dan kecemasan.

Kemudian metode ini bekerja dengan menyeimbangkan antara hipotalamus anterior dan posterior inti yang melalui pengurangan sistem saraf simpatik sehingga mencegah efek samping dari stress dan kecemasan serta meningkatkan relasasi tubuh dan pikiran.

Autogenic training merupakan salah satu metode untuk menurunkan tingkat kecemasan seseorang, teknik ini merupakan proses dalam latihan mental dengan melibatkan unsur konsentrasi, mengarahkan tujuan ke suatu tujuan sesuai rencana, pengendalian perasaan, dan 
Ruslan Rusmana ${ }^{1}$, Budiman ${ }^{2}$, Ricky Ferari ${ }^{3}$

psikofisik. Bahwa autogenic training berkontribusi pada penurunan ketegangan, kecemasan, dan gejala somatic.

Dalam hasil penelitiannya Kecemasan bersumber dari 3 aspek indikator yaitu kompetitif anxiety, kognitif anxiety dan somatic anxiety (Kumbara, Hengki Metra, Yogi Ilham, 2019). Sejalan dengan hal tersebut (Hooi et al., 2020) mengatakan bahwa autogenic training dapat digunakan dalam mengelola kecemasan bagi keadaan multidimensi dari atlet sebelum kompetisi.

Kemudian hasil penelitian (Purnamasari, 2019) mengatakan bahwa latihan relaksasi otot dengan metode progresif dan autogenic training berpengaruh signifikan terhadap pemulihan atlet judo. Kegiatan ini menginduksi perubahan langsung yang lebih tinggi pada kecemasan keadaan multidimensi jika dibandingkan dengan psikofisiologis.

Dengan demikian model struktural ini memberikan dampak dasar teoritis bagi psikolog olahraga untuk meningkatkan manajemen kecemasan untuk atlet mereka sebelum kompetisi. Autogenic training sering diterapkan dalam pengaturan grup. Bukti klinis dan bukti dari banyak penelitian terkontrol lainnya menunjukkan bahwa pengaturan kelompok juga tepa.

Setelah kelebihan stres dihilangkan, apa pun penyebabnya, individu tersebut lebih siap untuk mengatasi aspek lain dari diri mereka sendiri. Autogenic training (Widiastuti, 2015) Autogenic training lebih menekankan pada selfsugestion atau pemberian sugesti kepada diri sendiri.

Akan membantu tubuh untuk membawa perintah melalui autosugesti untuk rileks sehingga dapat mengendalikan pernafasan, tekanan darah, denyut jantung serta suhu tubuh. Imajinasi visual dan mantra-mantra verbal yang membuat tubuh merasa hangat, berat dan santai merupakan standar latihan relaxation autogenic training. Tujuan dari praktik relaksasi autogenik ini adalah menekankan sugesti pada diri sendiri untuk lebih tenang, ringan dan hangat sehingga tubuh menjadi rileks.

Perubahan-perubahan yang terjadi selama maupun setelah melaksanakan relaksasi autogenik akan memengaruhi kerja saraf otonom. Ketika pikiran sudah mulai tenang, ringan dan hangat maka pemain akan lebih fokus dalam shooting saat penalty sehingga dapat menunjukkan performa terbaiknya. Teknik ini merupakan salah satu cara membantu pemain sepak bola yang sedang mengalami ketegangan atau stres fisik dan psikologis dengan menekankan pada latihan mengatur pikiran. Dengan demikian pemain dapat mengontrol diri ketika terjadi rasa ketegangan dan stress yang membuat pemain merasa dalam kondisi tidak nyaman.

Hasil penelitian Progressive Muscle Relaxation (PMR) Training mempengaruhi penurunan taraf kecemasan. Baik progressive muscle relaxation maupun autogenic training dinilai bisa mengurangi faktor resiko tidak maksimalnya shooting pemain melalui penekanan tingkat kecemasan pemain (Nurkemala, 2019). Hal tersebut sesuai dengan yang di katakan oleh (Of, 2018) bahwa progressive muscle relaxation muscle dan autogenic training memiliki kontribusi terhadap pelatihan keterampilan mental guna mengurangi kecemasan.

Namun samapai dengan saat ini penelitian yang membandingkan kedua model ini sehingga belum diketahui metode mana yang memiliki efektivitas yang lebih baik dalam mengurangi faktor penurunan kemampuan shooting penalty akibat gangguan kecemasan pemainn.

Oleh karenya urgensi permasalahan ini diperlukan penelitian lebih lanjut untuk mengetahui keefektifan kedua model ini dalam upaya meningkatkan hasil shooting penalty pemain sepak bola.

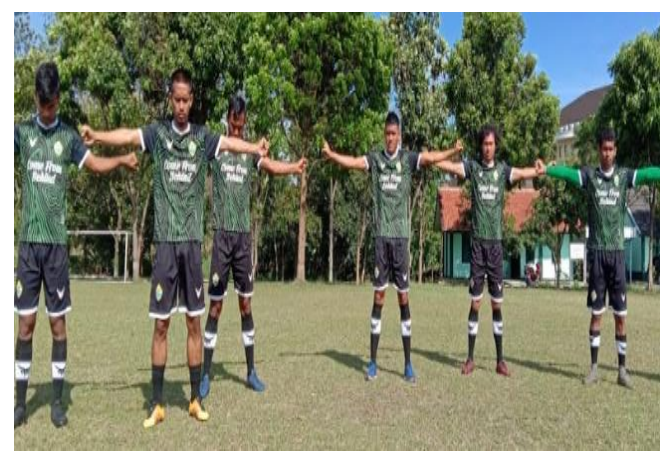

Gambar 1.

Latihan autogenic training dan progressive relaxation

Kelompok otot, instruksi dan lokasi otot yang dilatih:

a. Lengan kanan dan lengan kiri 
Lokasi: otot leher bagian samping

tangan kiri dan rasakan ketegangan

dalam otot disekitar tangan kanan dan kiri, rileks. (biarkan jari tangan terbuka dengan bebas).

Lokasi otot: otot bagian belakang lengan kanan-kiri, pergelangan tangan kanan dan kiri.

b. Pergelangan tangan

Instruksi: Tekuk pergelangan tangan ke belakang (hyper extention), kearah punggung rileks.

Lokasi otot: pergelangan tangan, jari tangan, lengan bawah

c. Lengan atas

Intruksi: Tekuk sikut mendekati bahu sampai terjadi ketegangan pada otot biceps, rileks.

Lokasi otot: otot biceps

d. Bahu

Instruksi: gerakan bahu keatas mengarah pada telinga, rileks (jatuhkan bahu ke posisi awal)

Lokasi: otot bahu, otot leher bagian bawah

e. Dahi

Instruksi: Kerutkan dahi dengan cara menaikan alis mata, rileks

Lokasi: otot dahi

f. Mata

Intruksi: Tutup mata dengan keras, rileks Lokasi: otot sekitar mata, otot kelopak mata

g. Dagu

Instruksi: Regang otot dagu dengan keras, rileks

Lokasi: otot dagu, otot pipi

h. Lidah

Intruksi: tekankan lidah melawan langit-langit bagian mulut, rileks

Lokasi: daerah sekitar lidah

i. Mulut

Intruksi: tekan kedua bibir secara bersama-sama dengan keras dan rileks.

Lokasi: daerah sekitar mulut

j. Leher

Instruksi: gerakan kepala kearah kanan-kiri luruskan atau rileks.

\section{METODE}

Jenis penelitian ini adalah jenis penelitian kuantitatif dengan metode yang digunakan dalam penelitian ini adalah metode eksperimen. Penggunaan metode eksperimen ini disesuaikan dengan tujuan penelitian yaitu untuk mengetahui perbedaan pengaruh penerapan metode progressive muscle relaxation dengan metode autogenic training terhadap hasil shooting penalty sepak bola.

Penelitian ini dilaksanakan di PSKC Kota Cimahi Jawa Barat.Teknik pengambilan sampel dalam penelitian ini menggunakan random sampling sebanyak 32 orang atlet Liga dua dan elit pro PSKC Cimahi. Instrumen yang digunakan menggunakan shooting penalti (Ali et al., 2014). Desain yang digunakan yaitu randomize pretest postest

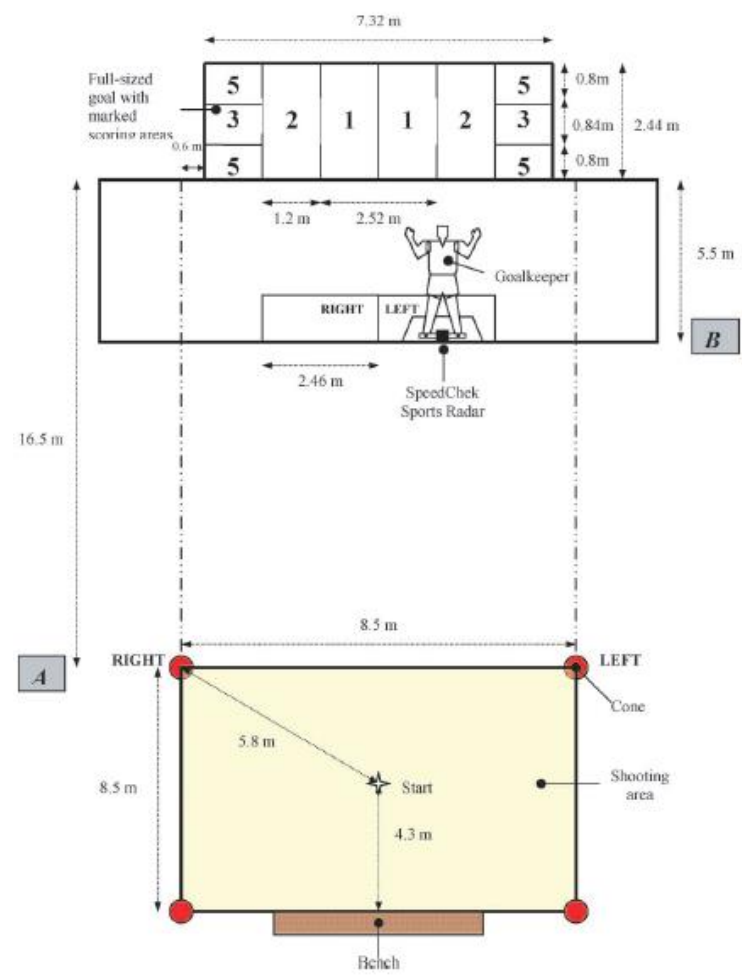

Gambar 2. Instrumen shooting penalty

\section{HASIL DAN PEMBAHASAN Hasil Penelitian}

Penelitian ini dilakukan untuk mengetahui pengaruh latihan autogenic training dan iprogressive muscle relaxation dalam tendangan penalti sepak bola di PSKC Cimahi. Hasil 
Persyaratan pengujian analisis data yang pertama adalah menguji normalitas. Uji normalitas yang digunakan dalam penelitian ini adalah uji one kolmogorov smirnov $z$ melalui SPSS 23 dengan ketentuan apabila nilai signifikansi kurang dari 0,05 (Sig. < 0,05) maka data berdistribusi tidak normal, sedangkan apbila nilai signifikansi lebih dari 0,05 (Sig. > 0,05) maka data berdistribusi normal.

Hasil perhitungan uji normalitas data hasil shooting penalti sepak bola pada kelompok kelompok latihan progressive muscle relaxation (PMR) dan autogenic training (AT) dapat dilihat dari hasil output diatas dapat dipaparkan hasil sebagai berikut: 1) Tabel uji normalitas di atas menunjukan untuk data hasil shooting penalti sepak bola pada pretest kelompok progressive muscle relaxation (PMR) diketahui bahwa nilai $\mathrm{KS}=1,307$ dan Signifikansi (Sig.) $=0,066>$ 0,05 maka Ho diterima, dengan demikian distribusi data dinyatakan normal; 2) Untuk data posttest kelompok progressive muscle relaxation (PMR) dengan nilai KS $=1,341$ dan Signifikansi (Sig.) $=0,055>0,05$ maka Ho diterima, dengan demikian distribusi data dinyatakan normal.

3) untuk hasil perhitungan uji normalitas data hasil shooting penalti sepak bola pada pretest kelompok autogenic training (AT) dari tabel di atas diketahui bahwa nilai $\mathrm{KS}=0,953$ dan Signifikansi (Sig.) $=0,324>0,05$ maka Ho diterima, dengan demikian distribusi data dinyatakan normal; 4) Untuk data posttest kelompok autogenic training (AT) dengan nilai $\mathrm{KS}=1,432$ dan Signifikansi (Sig.) $=0,033>$ 0,05 maka Ho diterima, dengan demikian distribusi data dinyatakan normal.Pembahasan

Langkah berikutnya untuk persyaratan pengujian statistik adalah uji homogenitas. Statistik yang digunakan untuk menguji homogenitas adalah uji statistik one way anova melalui SPSS 23 dengan ketentuan apabila (Sig.) $>0,05$ maka data homogen, sedangkan bila (Sig.) $<0,05$ data tidak homogen.

Hasil perhitungan uji normalitas data hasil shooting penalti sepak bola pada kelompok latihan progressive muscle relaxation (PMR) dan autogenic training (AT) dapat dilihat pada tabel 2.

Tabel 2 . Uji homogenitas PMR dan AT

\begin{tabular}{llll}
\hline & $\begin{array}{l}\text { Leven } \\
\text { Statistic }\end{array}$ & Fungsi & Keterangan \\
\hline PMR & 0,142 & 0,709 & $\begin{array}{l}\text { Data } \\
\text { homogen }\end{array}$ \\
\hline
\end{tabular}

pada tabel 1. Tabel 1. Hasil uji normalitas data kelompok latihan PMR dan AT

\begin{tabular}{|c|c|c|c|}
\hline & $\begin{array}{l}\text { Kolmogorv- } \\
\text { Smirnov }\end{array}$ & Fungsi & Keterangan \\
\hline pretest & 1,307 & 0,066 & Data \\
\hline$P M R$ & & & Normal \\
\hline Post & 1,341 & 0,055 & Data \\
\hline $\begin{array}{c}\text { test } \\
\text { PMR }\end{array}$ & & & Normal \\
\hline $\begin{array}{c}\text { Preetest } \\
\text { AT }\end{array}$ & 0,953 & 0,324 & $\begin{array}{l}\text { Data } \\
\text { Normal }\end{array}$ \\
\hline $\begin{array}{c}\text { Postes } \\
\text { AT }\end{array}$ & 1,432 & 0,333 & $\begin{array}{l}\text { Data } \\
\text { Normal }\end{array}$ \\
\hline AT & 0,102 & 1,000 & $\begin{array}{l}\text { Data } \\
\text { homogen }\end{array}$ \\
\hline
\end{tabular}

Dari tabel di atas perhitungan uji homogenitas pada kelompok progressive muscle relaxation (PMR) diketahui bahwa nilai leven statistic $=0,142$ dan signifikansi (Sig.) $=0,709$ > 0,05 maka Ho diterima, dengan demikian distribusi data dinyatakan homogen. Kemudian hasil perhitungan uji homogenitas pada kelompok autogenic training (AT) dari tabel di atas diketahui bahwa nilai leven statistic $=0,000$ dan Signifikansi (Sig.) $=1,00>0,05$ maka Ho diterima, dengan demikian distribusi data dinyatakan homogen.

Statistik yang digunakan untuk menguji hipotesis adalah uji statistik paired samples test melalui SPSS 23 dengan ketentuan sebagai berikut:

Hipotesis progressive muscle relaxation (PMR) terhadap hasil shooting penalti sepak bola:

a) $\mathrm{H}_{0}=$ Tidak terdapat Pengaruh signifikan progressive muscle relaxation (PMR) terhadap hasil shooting penalti sepak bola

b) $\mathrm{H}_{1}=$ Terdapat Pengaruh signifikan progressive muscle relaxation (PMR) terhadap hasil shooting penalti sepak bola

Hipotesis progressive muscle relaxation (PMR) terhadap hasil shooting penalti sepak bola:

a) $\mathrm{H}_{0}=$ Tidak terdapat Pengaruh signifikan autogenic training (AT) terhadap terhadap hasil shooting penalti sepak bola

b) $\mathrm{H}_{1}=$ Terdapat Pengaruh signifikan autogenic training (AT) terhadap 
terhadap hasil shooting penalti sepak bola

Kriteria Keputusan:

1. Nilai Signifikansi atau nilai signifikansi (Sig.) > 0,05, Ho diterima dan $\mathrm{Hi}$ ditolak

2. Nilai Signifikansi atau nilai signifikansi (Sig.) < 0,05, Ho ditolak dan Hi diterma Pengujian hipotesis ini melalui SPSS 23.

Hasil perhitungan uji hipotesis data menggunakan uji paired sample test pada kelompok progressive muscle relaxation (PMR) dan autogenic training (AT) dapat dilihat pada tabel 3.

Tabel 3 . Uji paired sample test PMR dan AT

\begin{tabular}{cllll}
\hline & T & $\begin{array}{l}\text { Sig.(2- } \\
\text { tailed) }\end{array}$ & Keputusan & Kesimpulan \\
\hline PMR & 0,521 & 0,000 & Ho Ditolak & $\begin{array}{l}\text { Pengaruh } \\
\text { Signifikan }\end{array}$ \\
AT & 4,392 & 0,001 & Ho DItolak & $\begin{array}{l}\text { Pengaruh } \\
\text { Signifikan }\end{array}$ \\
& & & & S
\end{tabular}

\section{Pembahasan}

Dalam penelitian ini bermaksud untuk mnegetahui perbedaan pengaruh antara autogenic training dengan progressive muscle relaxaation di PSKC Kota Cimahi dengan sampel 33 orang PSKC yang bermain di liga dua dan elite pro yang berjumlah 33 orang. Pengambilan sampel yang digunakan adalah total sampling . teknik pengambilan data adalah dengan test hasil shooting penalty dengan kesempatan satu kali.

Data yang diperoleh dianalisis dengan uji normalitas pretest PMR 0,066, pretest AT 0,324 dan postest PMR 0,055 postest AT 0,333 kemudian di uji homogenitas bahwa kedua data diketahui dengan hasil data homogen dan hasil uji paired PMR dan AT memberikan pengaruh yang signifikan dangan angka PMR 0,521 dan AT 4,392. Dengan hasil tidak terdapat perbedaan pengaruh antara PMR dan AT terhadap hasil shooting penalty sepak bola.

Ketangguhan mental merupakan kumpulan variabel psikologis positif. Ini termasuk termotivasi secara intrinsik, memiliki tingkat kepercayaan diri yang tinggi, kemampuan untuk mempertahankan fokus dan memfokuskan kembali setelah kecemasan, dan mampu mengatasi, dan bertahan mengikuti, kemunduran yang tak terhindarkan.

Temuan saat ini juga konsisten dengan penelitian tentang pengembangan pemain di sepak bola PSKC Kota Cimahi, Selain kesesuaian dengan temuan sebelumnya, ada juga beberapa temuan baru utama yang muncul dari studi sekarang. Pertama, sementara model autogenic training dan progressive muscle relaxation.

Pelatih sepak bola memandang pemain yang memiliki mental paling tangguh mampu menguasai dan mengandalikan dirinya, di samping komitmen untuk keunggulan yang menerjemahkan hasrat menjadi kesuksesan. Berdasarkan uraian data temuan diatas yang diperkuat dengan analisis statistik, dapat di nyatakan bahwa autogenic training dan progressive muscle relaxation sangat signifikan terhadap hasil shooting penalti sepak bola.

Berdasarkan output diatas pada kelompok progressive muscle relaxation (PMR) diperoleh nilai Sig.(2-tailed) sebesar 0,000 < 0,05 . Sesuai dasar pengambilan keputusan Paired Samples Test, maka dapat disimpulkan Ho ditolak Hi diterima, yang artinya bahwa terdapat pengaruh signifikan latihan progressive muscle relaxation (PMR) terhadap hasil shooting penalti sepak bola.

Selanjutnya, berdasarkan output diatas pada kelompok autogenic training (AT) diperoleh nilai Sig.(2-tailed) sebesar 0,001 < 0,05 . Sesuai dasar pengambilan keputusan paired samples test, maka dapat disimpulkan Ho ditolak $\mathrm{Hi}$ diterima, yang artinya bahwa terdapat pengaruh signifikan latihan autogenic training (AT) terhadap hasil shooting penalti sepak bola. Pengujian hipotesis ini melalui SPSS 23.

Hasil perhitungan uji hipotesis data menggunakan independent samples test dapat dilihat pada tabel 4 . 
Tabel 4 . Uji beda gain skor kelompok PMR dan AT

\begin{tabular}{clll}
\hline T & $\begin{array}{l}\text { Sig.(2- } \\
\text { tailed) }\end{array}$ & Keputusan & Kesimpulan \\
\hline 1,744 & 0,091 & Ho Diterima & $\begin{array}{l}\text { Tidak terdapat } \\
\text { perbedaan pengaruh }\end{array}$ \\
\hline
\end{tabular}

Dari output SPSS tersebut menunjukan Nilai $\mathrm{t}$ ( $\mathrm{t}$ hitung) $=1,744$ dan Signifikansi $=$ $0,091>0,05$ maka dapat diartikan bahwa tidak terdapat perbedaan yang signifikan antara hasil shooing penalti sepak bola pada pemain PSKC Cimahi yang menggunakan latihan progressive muscle relaxation (PMR) dengan autogenic training (AT).

\section{KESIMPULAN}

Keterampilan mental mampu mengelola dan mengatasi diri sangat penting salah satunya keterampilan mampu mengimplementasikan autogenic training dan progressive muscle relaxation terutama dalam tingkatan prestasi yang lebih tinggi seperti pada penelitian ini di tingkatan pemain elite pro liga dua sepak bola Indonesia.

Artinya pada atlet elite pro liga dua sepak bola Indonesia mental sangat menentukan hasil tendangan penalti karena atlet liga dua Indonesia sudah termasuk kategori atlet profesional mereka secara teknik dan keterampilan motorik sudah mahir akan tetapi hal teknik, taktik, strategi akan hilang manakala mental atlet tidak bagus salah satunya dengan relaksasi dan autogenic training untuk mengatasi rasa cemas.

Berdasarkan pada uraian hasil data penelitian maka dapat disimpulkan bahwa latihan progressive muscle relaxatioan dan autogenic training dalam shooting penalty sepak bola sama sama berpengaruh dalam meningkatkan hasil shooting pemain sepak bola di PSKC Kota Cimahi dan model latihan mental ini bisa digunakan dimasukan kedalam peridesasi latihan supaya sudah terbiasa dapat menguasi diri sendiri secara otomatis.

\section{DAFTAR PUSTAKA}

Ali, A., Williams, C., Hulse, M., Strudwick, A., Reddin, J., Eldred, J., Hirst, M., \& Mcgregor, S. (2014). Reliability and validity of two tests of soccer skill. November 2014, 37-41. https://doi.org/10.1080/0264041060115047
0

Astuti Ary, Anggorowati, J. A. (2017). Jurnal SMART Keperawatan Sekolah Tinggi Ilmu Kesehatan (STIKes) Karya Husada Semarang www.stikesyahoedsmg.ac.id/ojs/index.php/s jkp(perawat) 31.4(2), 31-44.

Effendi, H. (2017). Mengatasi Kecemasan Pada Atlet Sebelum Pertandingan Melalui Pendekatan Kognitif. Jurnal Menssana, 2(1), 37-44.

Hampson, N., King, L., Eriksson, L. M., \& Smee, H. (2020). The effects of relaxation training on depression and anxiety in people living with long-term neurological conditions. Disability and Rehabilitation, 42(15), 2100-2105.

https://doi.org/10.1080/09638288.2018.155 4009

Hooi, L. B., Wah, T. E., van Bac, N., Khoa, P. T. A., Siswantoyo, Kumar, R., \& Danh Na, P. (2020). A new structural equation modeling of psychophysiological measures and multidimensional state anxiety induced by autogenic training. International Journal of Psychosocial Rehabilitation, 24(5), 66196631. https://doi.org/10.37200/IJPR/V24I5/PR20 20648

Horikawa, M., \& Yagi, A. (2012). The relationships among trait anxiety, state anxiety and the goal performance of penalty shoot-out by university soccer players. PLOS ONE, 7(4), 4-8. https://doi.org/10.1371/journal.pone.00357 27

Jamil, M., Littman, P., \& Beato, M. (2020). Investigating inter-league and inter-nation variations of key determinants for penalty success across European football. International Journal of Performance Analysis in Sport, 20(5), 892-907. https://doi.org/10.1080/24748668.2020.179 4720

Komarudin. (2015). Psikologi Olahraga (Y. Hidayat (ed.)). PT Remaja Rosdakarya. 
Kumbara, Hengki Metra, Yogi Ilham, Z. (2019). Analisis Tingkat Kecemasan (Anxiety) Dalam Menghadapi Pertandingan Atlet Sepak Bola Kabupaten Banyuasin Pada Porprov 2017. Jurnal Ilmu Keolahragaan, 17(2), 28. https://doi.org/10.24114/jik.v17i2.12299

Lolak, S., Connors, G. L., Sheridan, M. J., \& Wise, T. N. (2010). Effects of progressive muscle relaxation training on anxiety and depression in patients enrolled in an outpatient pulmonary rehabilitation program. Psychotherapy and Psychosomatics, 77(2), 119-125. https://doi.org/10.1159/000112889

Makaruk, H., Porter, J. M., Bodasińska, A., \& Palmer, S. (2020). Optimizing the penalty kick under external focus of attention and autonomy support instructions. European Journal of Sport Science, O(0), 1-18. https://doi.org/10.1080/17461391.2020.172 0829

Mattle, S., Birrer, D., \& Elfering, A. (2020). Feasibility of Hypnosis on Performance in Air Rifle Shooting Competition. International Journal of Clinical and Experimental Hypnosis, 68(4), 521-529. https://doi.org/10.1080/00207144.2020.179 9655

Nurkemala, S. (2019). Pengaruh Progressive Muscle Relaxation Training Terhadap Taraf Kecemasan Tekanan Darah Tinggi. Jurnal Psikologi : Media Ilmiah Psikologi, 17.

Of, C. N. for M. and A. T. (CANMAT) and I. S. for B. D. (ISBD) 2018 guidelines for the management. (2018). Canadian Network for Mood and Anxiety Treatments (CANMAT) and International Society for Bipolar Disorders (ISBD) 2018 guidelines for the management of. Patients with Bipolar Disorder. https://doi.org/DOI: 10.1111/bdi.1260

Purnamasari, I. (2019). Pengaruh Latihan Relaksasi Otot dengan Metode Progresif dan Autogenik terhadap Pemulihan Atlet
Judo. 1-11.

Russell, S., Jenkins, D., Rynne, S., Halson, S. L., \& Kelly, V. (2019). What is mental fatigue in elite sport? Perceptions from athletes and staff. European Journal of Sport Science, 19(10), 1367-1376. https://doi.org/10.1080/17461391.2019.161 8397

Sangari, M., Fotrousi, F., \& Masrour, F. F. (2012). Relationship between mental skill and competitive anxiety in female national football players. World Applied Sciences Journal, 20(8), 1175-1178. https://doi.org/10.5829/idosi.wasj.2012.20. 08.2813

Thompson, C. J., Noon, M., Towlson, C., Perry, J., Coutts, A. J., Harper, L. D., Skorski, S., Smith, M. R., Barrett, S., Thompson, C. J., Noon, M., Towlson, C., Perry, J., Aaron, J., Harper, L. D., Skorski, S., Smith, M. R., Barrett, S., Meyer, T., \& Harper, L. D. (2020). Understanding the presence of mental fatigue in English academy soccer players. Journal of Sports Sciences, 00(00), $1-7$.

https://doi.org/10.1080/02640414.2020.174 6597

Widiastuti. (2015). Tes Pengukuran Dalam Olahraga. Rajagrafindo.

Wunderlich, F., Berge, F., Memmert, D., \& Rein, R. (2020). Almost a lottery: the influence of team strength on success in penalty shootouts. International Journal of Performance Analysis in Sport, 20(5), 857869.

https://doi.org/10.1080/24748668.2020.179 9171 